\title{
A look from inside SPIE student chapters: way to enhance professional skills and share experience
}

\section{Y. Filipov}

Y. V. Filipov, "A look from inside SPIE student chapters: way to enhance professional skills and share experience," Proc. SPIE 9664, Ninth International Topical Meeting on Education and Training in Optics and Photonics, 96640 U (24 October 2005); doi: 10.1117/12.2207791 


\title{
Ref ETOP106
}

\section{SPIE student chapters ? way to enhance professional skills and share experience (Look from inside)}

\author{
Y.V. Filipov
}

\begin{abstract}
In modern world we can perceive that fast changing industry technologies requires increasing educational level and professional skills of employees. Classical education meant to give fundamental knowledge and can?t cover edge of science progress and keep this accelerated pace. It?s normal situation because there is some time lag between new inventions and their including into educational program.

That is why today role of science societies are increasing. Advantages of science societies are especially important in formation new specialists. These advantages are realized in activity of student chapter of international science societies.
\end{abstract}

\section{Summary}

SPIE student chapters ? way to enhance professional skills and share experience (Look from inside) Y.V. Filipov Taras Shevchenko Kyiv National University, Glushkova Prosp. 2, Kyiv 03127, Ukraine filipov@univ.kiev.ua

In modern world we can perceive that fast changing industry technologies requires increasing educational level and professional skills of employees. Classical education meant to give fundamental knowledge and can?t cover edge of science progress and keep this accelerated pace. It?s normal situation because there is some time lag between new inventions and their including into educational program.

That is why today role of science societies are increasing. Advantages of science societies are especially important in formation new specialists. These advantages are realized in activity of student chapter of international science societies.

One of the leading science societies in optics and photonics is SPIE ?

the International Society for Optical Engineering. SPIE activity is multidirectional; one of them is founding and developing student chapters all over the world. Each student chapter is an important link in a global educational network. SPIE believes the future belongs to optics and photonics, and the future of these technologies is in the hands of young scientists.

In my university we establish the Taras Shevchenko Kyiv National University SPIE Student Chapter. Our chapter activity is dedicated to improve knowledge on optics and photonics through Conferences, Lectures, Publications and Collaboration. SPIE provides extensive support to students through information exchange, financial assistance, and exposure to cutting-edge technology developments, here are a few opportunities:

- $\quad$ Organizing an informal lecture and chapter meetings organized 4

times a year plus special meetings with special guests, such as meeting with 2005 SPIE President Malgorzata Kujawinska on May 2004, and meeting with Chair of SPIE Membership Committee James J. Grote on May 2004, and Executive Director of Rozhdestvensky Optical Society Vladimir Arpishkin on June 2004.

- $\quad$ Participation in science fairs through secondary educational

outreach and mentoring of secondary science and technology students.

- $\quad$ Invited speakers from research laboratories and other

universities. We request a speaker from SPIEl's database of distinguished professionals.

- $\quad$ Industry tours, as our industry practical tour to Izum Optical 
glass factory in Izum, Kharkiv region, Ukraine.

Creation and maintenance of chapter web page - a developed web

site www.spie.kiev.ua with interest information about chapter, planned events, activity, list of members and other useful information. Link the chapter web page to SPIE web.

- $\quad$ Participation of an officer in the Student Chapter Orientation

Program with Career Development - find an internship or career at SPIEWorks.com, the premier web site for optics and photonics companies looking for talent.

- $\quad$ Learn about the latest optics and photonics technology by

reading your free subscription to ?OEmagazine?. And, with your online journals and books in SPIE Digital Library with discount. Know more about a specific technology - SPIE Student Member get one free Technical Group membership.

- $\quad$ Reports of special Student Chapter activities in the Student

Newsletter service and Online Discussion Forums.

- $\quad$ Travel support and registration costs associated with attending

an SPIE conference. Chapter members are first for consideration for individual travel support to present papers at SPIE meetings and special consideration for chapter groups traveling to SPIE conferences.

- $\quad$ Organizing self conference. Each autumn TSKNU SPIE Student Chapter helps to organize Annual International Young Scientists Conference I"Optics of High Technology Material Sciencel" SPO on Optics Division, Physics Department of Taras Shevchenko Kyiv National University. Topic of Conference includes 3 sessions: A. Nanotechnology, Thin Films and Coatings; B. Lasers and Optoelectronics; C. Biomedical Optics.

All this opportunities confirm what membership in SPIE is window into the global optics and photonics community. A Student Chapter offers an opportunity to learn and practice the leadership skills necessary to succeed as a professional in our field. Belonging to an SPIE Student Chapter makes member a part of a dynamic international network of students involved in innovative research programs. The extended network of Student Chapters facilitates connections with other university groups and opens doors for young scientists to communicate with established professionals working in the fields of optics, photonics and related disciplines. And our success will impact the future vitality of these fields.

SPIE unique research and missions have allowed SPIE to produce educational materials that engage student interest in science, technology, engineering, and math. Our goal is to create educational materials that are educationally sound, scientifically accurate, and matched to latest industry technologies standards. 